\title{
Toxicity of Sulfonamides especially antidiabetic Medicine for internal Use
}

\author{
(Study of Heinz-body: Report XXII)
}

By

\section{Assist.-Professor Hideo YOSHIDA M.D. and Yukio MATSUDA}

Medical Department of Kyoto Prefectural Medical School (Director: Prof. S. Tateishi M.D.)

We published these data at the 4th general meeting of the western branch of Japan Endocrinological Society (Folia Endocrinologica Japonica Vol. 32, No. 9, 756, 1956).

Since the outbreak of an accident of penicillin shock, penicillin has been refused by doctors and patients. So sulfonamides are expected to be resorted to again. On the other hand, BZ55, D860, Crebon and other sulfonamides have appeared as an antidiabetic medicine for internal use. The toxicity of sulfonamides on blood, kidney and liver has long been noticed. But it is easily supposed that the use of these sulfonamides for diabetes mellitus may take a long time.

Already, in 1944, one of us, Yoshida, published the study on toxicity of sulfonamides by Heinz-body as Table 1, (Journal of Kyoto Prefectural Medical University Vol. 41, No. 4, 811,

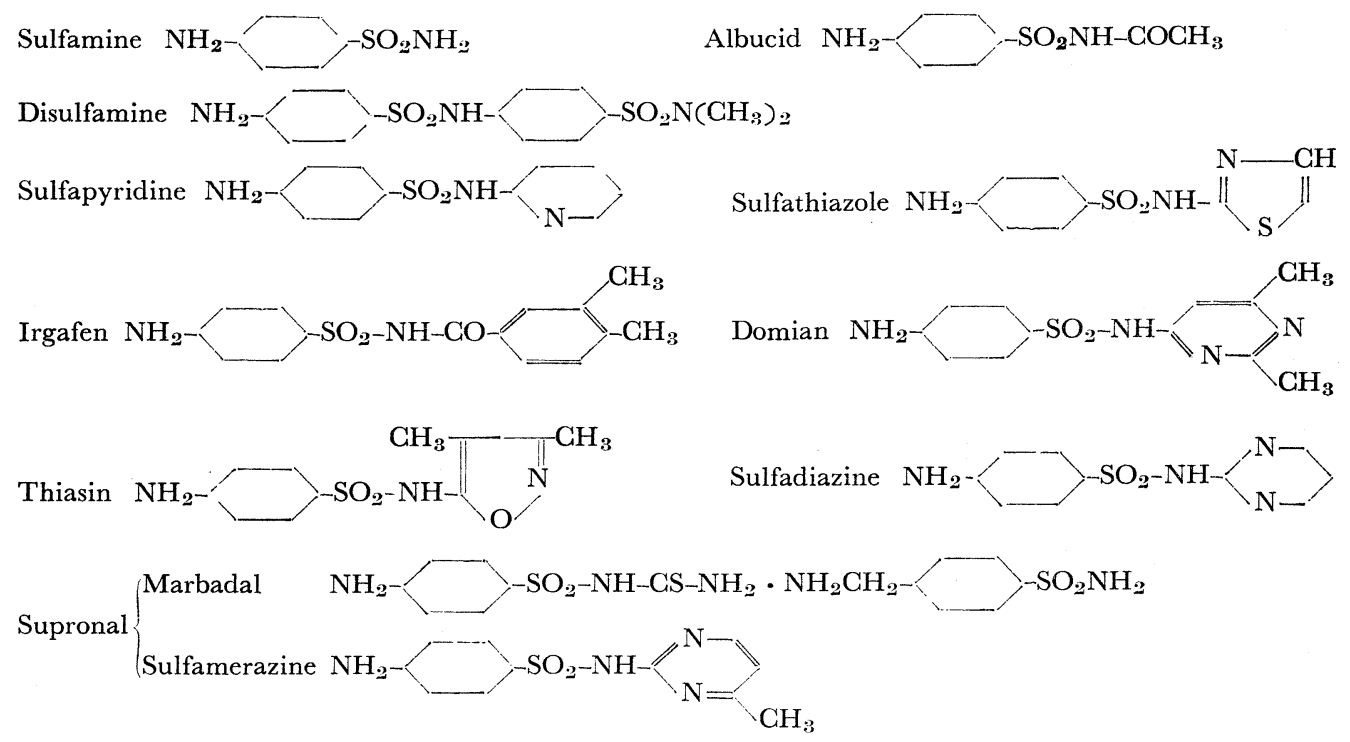

(TB-1) $\mathrm{CH}_{3}-\mathrm{CO}-\mathrm{NH}-\longrightarrow \mathrm{CH}=\mathrm{N}-\mathrm{NH}-\mathrm{CS}-\mathrm{NH}_{2}$

$\mathrm{BZ} 55 \mathrm{NH}_{2}-\mathrm{SO}_{2}-\mathrm{NH}-\mathrm{CO}-\mathrm{NH}-\mathrm{CH}_{2}-\mathrm{CH}_{2}-\mathrm{CH}_{2}-\mathrm{CH}_{3}$

$\mathrm{D} 860 \mathrm{CH}_{2}-\mathrm{SO}_{2}-\mathrm{NH}-\mathrm{CO}-\mathrm{NH}-\mathrm{CH}_{2}-\mathrm{CH}_{2}-\mathrm{CH}_{2}-\mathrm{CH}_{3}$

Grebon (I.B.T.D.) $\mathrm{NH}_{2}>-\mathrm{SO}_{2}-\mathrm{NH}$ 
1944). And now we have observed the toxicity of new sulfonamides, especially, antidiabetic medicine for internal use,- - on blood by Heinz-body and on liver and kidney by tissue respiration.

\section{Method}

We used white mice of 15-20 g. We gave the medicine per os with small kneading riceballs. After these mice have taken the medicine, we gave them more rice and vegetables. Every day we weighed the mice.

We take a little drop of blood from a tail of mouse and mix with a little drop of an $1 \%$ brillantcresylblue $-0.6 \%$ salt solution, which is covered with a cover glass. We observe 1000 erythrocytes and count the \% of erythrocytes, which have each Heinz-body in themselves, and thus we count reticulocytes, too.

After 6 daily $0.01 \mathrm{~g}$ per os medicated days, we killed mice and measured tissue respiration on $38^{\circ} \mathrm{C}$ with Warburg's apparatus and decided $\mathrm{QO}_{2}$ of dry weight $1 \mathrm{mg}$.

\section{Result}

The promille of erythrocyte with Heinz-body in blood of mice, which had been given

Table 1. The \%o of erythrocyte with Heinz-body in blood of mice, which had been given sulfonamides (by H. Yoshida 1944)

\begin{tabular}{|l|c|c|r|r|r|r|r|r|r|r|r|r|r|}
\hline \multicolumn{1}{|c}{ Medicine } & $\begin{array}{c}\text { Daily dose } \\
\text { per os (g) }\end{array}$ & $\begin{array}{c}\text { Medicated } \\
\text { days }\end{array}$ & Cases & 1 & 2 & 3 & 4 & 5 & 6 & 7 & 8 & 9 \\
\hline Sulfamine & 0.01 & $1-9$ & 6 & 2 & 14 & 169 & 454 & 550 & 631 & 769 & 750 & 772 \\
Albucid & 0.01 & $1-6$ & 5 & 1 & 9 & 8 & 6 & 34 & 39 & 52 & 51 & 72 & \\
& 0.03 & $7-9$ & $1-6$ & 5 & 0 & & 2 & 3 & 4 & 8 & 15 & 15 & 26 \\
Disulfamine & 0.01 & $7-9$ & $1-6$ & 28 & 0 & 20 & 180 & 375 & 550 & 630 & 670 & 700 & 680 \\
Sulfapyridine & 0.5 & 0.01 & $1-6$ & 12 & 1 & 2 & 1 & 0 & 0 & 1 & 0 & 0 & 1 \\
Sulfathiazole & 0.01 & $1-6$ & & & & & & & & & & & \\
& 0.02 & 0.03 & $1-6$ & & & & & & & & & &
\end{tabular}

Table 2. The \%o of erythrocyte with Heinz-body in blood of mice, which had been given new sulfonamides

\begin{tabular}{|l|r|r|r|r|r|r|r|r|r|r|r|r|r|}
\hline \multicolumn{1}{|c|}{ Medicine } & $\begin{array}{c}\text { Daily dose } \\
\text { per os (g) }\end{array}$ & $\begin{array}{c}\text { Medicated } \\
\text { days }\end{array}$ & Cases & 1 & 2 & 3 & 4 & 5 & 6 & 7 & 8 & 9 \\
\hline Irgafen & 0.01 & $1-6$ & 9 & 7 & 13 & 36 & 140 & 295 & 486 & 540 & & \\
Domian & 0.01 & $1-6$ & 5 & 2 & 4 & 6 & 9 & 7 & & 15 & 14 & 22 \\
Thiasin & 0.03 & $7-9$ & & & & & & & & & & & \\
& 0.01 & $1-6$ & 13 & 4 & 5 & 18 & 15 & 14 & 15 & 16 & 21 & 27 \\
Supronal & 0.03 & $7-9$ & $1-6$ & 8 & 8 & 11 & 45 & 167 & 223 & 298 & 676 & 803 & 785 \\
Sulfadiazine & 0.01 & 0.01 & $1-6$ & 6 & 5 & 17 & 25 & 42 & 38 & 51 & 76 & 92 & 60 \\
(TB-1) & 0.03 & $7-9$ & $1-6$ & 9 & 7 & 8 & 24 & 73 & 127 & 180 & & & \\
BZ55 & 0.01 & $1-6$ & 13 & 7 & 8 & 10 & 11 & 11 & 18 & 29 & 30 & \\
D860 & 0.01 & $1-6$ & $1-6$ & 24 & 4 & 5 & 4 & 5 & 7 & 3 & 3 & 7 & \\
Crebon & 0.01 & $1-6$ & 12 & 3 & 7 & 11 & 15 & 21 & 22 & 26 & 37 & \\
\hline
\end{tabular}

Vol. 32 No. 10 
daily $0.01 \mathrm{~g}$ sulfonamide per os six days long, is shown as Table 2.

Domian and Thiasin increase only a few Heinz-bodies and show very little toxicity on erythrocyte. Sulfadiazine also shows result like these, Supronal and Irgafan increase over $500 \%$ Heinz-bodies, and show very strong toxicity on erythrocyte.

BZ55 and Crebon show, after one week, about 30\% Heinz-body and have far less toxicity than sulfamine, sulfapyridine, Supronal or Irgafen, and have less toxicity than sulfadiazine or Albucid, too. BZ55 and Crebon show less toxicity than Thiasine, but it is a little stronger than sulfathiazole, disulfamine or Domian.

D860 has less toxicity than BZ55.

Tissue respiration of mice, which had been given daily $0.01 \mathrm{~g}$ sulfonamides per os 6 days long, is shown as Table 3.

Tissue respiration of mice, which had been given Irgafen, BZ55, D860 or Crebon, is quite equal to the control. And these sulfonamides are not poisonous for liver or kidney from the viewpoint of tissue respiration.

On the first or second medicated day, reticulocytes increase a little and, after about 5 days, they become very few.

Table 3. Tissue respiration of mice $\left(\mathrm{QO}_{2}\right.$ of dry weight $\left.1 \mathrm{mg}\right)$

A Control

\begin{tabular}{|c|c|c|}
\hline $\begin{array}{c}\text { Case } \\
\text { number }\end{array}$ & Liver & Kidney \\
\hline 1 & & 20.38 \\
2 & 11.26 & 17.83 \\
3 & 12.14 & 17.45 \\
4 & 12.61 & 20.57 \\
5 & 13.25 & \\
6 & 14.01 & \\
7 & 12.46 & \\
8 & 9.86 & 18.52 \\
9 & 16.87 & 20.20 \\
10 & 13.70 & 21.03 \\
11 & 12.80 & \\
12 & 13.24 & 20.68 \\
Average & 12.92 & 19.58 \\
\hline
\end{tabular}

B Irgafen

\begin{tabular}{|c|c|c|}
\hline $\begin{array}{c}\text { Case } \\
\text { number }\end{array}$ & Liver & Kidney \\
\hline 1 & 11.53 & 17.80 \\
2 & 13.63 & 23.02 \\
3 & 12.33 & 18.47 \\
4 & 13.13 & 21.38 \\
5 & 11.83 & 18.74 \\
Average & 12.49 & 19.88 \\
\hline
\end{tabular}

D $\quad$ D860

\begin{tabular}{|c|c|c|}
\hline $\begin{array}{c}\text { Case } \\
\text { number }\end{array}$ & Liver & Kidney \\
\hline 1 & 12.32 & 21.03 \\
2 & 12.69 & 20.50 \\
3 & 14.82 & 22.21 \\
4 & 10.58 & 19.97 \\
5 & 14.21 & 19.83 \\
Average & 12.92 & 20.70 \\
\hline
\end{tabular}

C $\quad$ BZ55

\begin{tabular}{|c|r|c|}
\hline $\begin{array}{c}\text { Case } \\
\text { number }\end{array}$ & Liver & Kidney \\
\hline 1 & 13.13 & 20.23 \\
2 & 9.53 & 17.19 \\
3 & 14.19 & 19.54 \\
4 & 16.88 & 19.67 \\
5 & 13.92 & 18.95 \\
Average & 13.53 & 19.11 \\
\hline
\end{tabular}

E Crebon

\begin{tabular}{|c|c|c|}
\hline $\begin{array}{c}\text { Case } \\
\text { number }\end{array}$ & Liver & Kidney \\
\hline 1 & 12.00 & 17.19 \\
2 & 12.31 & 16.00 \\
3 & 15.08 & 22.36 \\
4 & 15.69 & 20.48 \\
5 & 13.27 & 18.58 \\
Average & 13.67 & 18.92 \\
\hline
\end{tabular}

\section{Summary}

1. From the viewpoint of Heinz-body, Domian, Thiasin and sulfadiazine have little toxicity, while Supronal and Irgafen show very strong toxicity. But this toxicity may come from slow separation, and the effect is another problem.

2. Even Irgafen which has very strong toxicity from the viewpoint of Heinz-body, shows no toxicity for liver and kidney viewed from the point of tissue respiration.

3. BZ55, D860 and Crebon have a little toxicity from the viewpoint of Heinz-body, and show no toxicity for liver and kidney viewed from the point of tissue respiration. 